\title{
У TATAR PEDLARS IN THE GRAND DUCHY OF FINLAND IN THE LATE NINETEENTH CENTURY
}

\author{
Johanna Wassholm \\ Åbo Akademi University
}

\begin{abstract}
In the 1880s, the arrival of a new group of traders was noted in Finnish- and Swedish-language newspapers published in the Grand Duchy of Finland. The newcomers were Muslim Tatars, petty traders originating in a few villages south of Nizhny Novgorod. They found a livelihood in market and itinerant trade in the Russian Empire. This article examines depictions of Tatar mobile traders in the late nineteenth-century press in Finland. While petty trade has left fragmentary traces in historical sources, the Finnish National Library's digital newspaper database offers new possibilities to create an overview of how the press depicted relations between the early Tatar itinerant traders and the local sedentary society. Through the concepts of space and practices, the article discusses the following topics: fairs as a space for ethnic encounters, Tatar trading practices and interaction with local customers, the traders' use of space and tactics in relation to formal regulation and the fairs as a "threatening" space. The article contributes new knowledge on the early period of Tatar presence in Finland, relatively invisible in previous research, and on the multiethnic character of late nineteenth-century petty trade.
\end{abstract}

\section{INTRODUCTION}

In the 1880s, Finnish- and Swedish-language newspapers in the Grand Duchy of Finland published observations about a previously unknown group of traders. Reporters and correspondents observed that "Orientals" were roaming the country, engaging in itinerary trade in rural regions and peddling cloths, carpets, furs and a multitude of other "inexpensive but poor-quality" goods in urban markets and fairs (Åbo Tidning 23.9.1885: 3). As newcomers on the trading scene, they attracted attention due to their allegedly insistent trading practices and their language, clothing, appearance and religion, which made them stand out among the majority population. These pedlars were Muslim Tatars, most of whom came from the Sergach district in Nizhny Novgorod province. A smaller number arrived from the regions of Kazan and Simbirsk (Leitzinger 1999: 25; Baibulat 2004: 14; Halén 2011: 3; Nevalainen 2016: 21-22).

The late nineteenth century was a period of liberalization and economic growth in Finland. Petty trade played an important role in answering a growing demand for consumer goods especially among the lower strata of society (Hjerppe 1989: 41-42; Mikkola \& Stark 2009: 4-5). The trading scene in Finland was already characterized by an ethnic, linguistic and religious heterogeneity. In addition to Tatars, the local population encountered and interacted with Russians,

Volume 8(2) (2020), pp. 8-24

DOI $10.23993 /$ store. 83460

Licensed under Creative Commons Attribution 3.0 License.

ISSN: 2323-5209

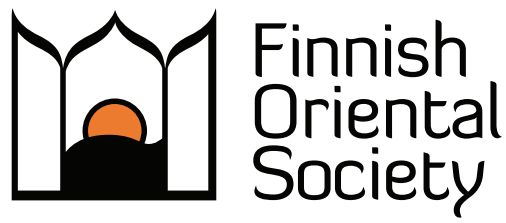


Karelians, Jews, Poles and Estonians, all originating from various parts of the multi-ethnic Russian Empire (Häkkinen 2005: 249; Klinge 1984: 14-15).

The heterogeneity can be explained by two factors. Ethnic minorities have played an important role in petty trade in general, in history as well as today, and various forms of petty trade have typically offered a means of livelihood to newcomers in society (Wassholm \& Sundelin 2018b: 196-197). Furthermore, the visibility that traders from Russian provinces enjoyed is explained by geographical proximity and geopolitics. As an integrated part of Sweden from the Middle Ages, Finland was incorporated into the Russian Empire as an autonomous Grand Duchy after the Russo-Swedish war of 1808-1809.

In the early stages of Tatar presence in Finland, most traders were only partially mobile. The male traders who arrived first tended the farmland in their home region in the summer and engaged in small-scale trade in Moscow, Saint Petersburg and Finland during winter. The wives and children remained in the home villages until the men had established themselves to such an extent that they could support and look after the family in the new environment. The first Tatars arrived in Finland in the late 1860s, but only towards the end of the century did whole families start to settle permanently in the Grand Duchy (Leitzinger 1999: 25-27; Harviainen 2001: 4).

After the establishment of the Soviet Union in 1922, the Tatars had to make a definitive choice between Russia and Finland. The unstable conditions in their home region played a crucial role in their decisions. World War I and the Revolution had ruined the Russian economy, food shortages resulted in famines and the prospects of surviving in a region ravaged by civil war were uncertain. The possibilities to maintain contacts with the home villages weakened as the border between Finland and the Soviet Union was closing in the 1920s. The Tatar families who chose to settle permanently in Finland, where the community exists to this day, consisted of around 1,000 individuals (Ståhlberg 2012).

\section{AIM AND SOURCES}

In this article, I examine how the early Tatar pedlars were depicted in the Finnish- and Swedishlanguage press in Finland in the late nineteenth century and the first years of the twentieth century. To analyse the topic, I use the concepts of space and practices. Frank Trentmann (2010: 50) maintains that the concept of space offers a fruitful point of departure for analysing consumption as an everyday practice. It helps to illustrate where consumption takes place and to view it in relation to public life and politics.

The concept of space is also central in cultural theoretician Michel de Certeau's seminal work The Practice of Everyday Life. De Certeau argues that social relations in a particular physical place can be studied through everyday practices, more specifically through the concepts of strategy and tactics. By strategy he refers to formal power regulating the activities taking place in a specific physical space. Tactics signify the informal practices which those who are affected by the formal regulation use to challenge the strategy (de Certeau 1984; Koivunen \& Syrjämaa 2011). In the context of Tatar petty trade, I define strategy as the authorities' formal power to decide who has the right to trade, in which places and at what times. Tactics refer to the informal practices applied by the traders in and outside the trading places.

I examine the topic from four points of view. First, I analyse how the Tatars are depicted in the context of the trading places as arenas for multi-ethnic encounters. Special focus is placed on how their emergence in these spaces from the early 1880 s is described. Second, I examine depictions of the Tatars' goods and trading practices and of their interaction with their 
customers. Third, I study the Tatar traders' relations with local authorities, more specifically how they used tactics to challenge the formal trading regulations and how they formed their own space in relation to the restrictions imposed on their trade. Fourth, I examine the fairs as a "threatening" space from which the authorities tried to ban Tatars and other traders originating in Russia, fearing the spread of epidemic diseases such as cholera.

The source material consists of articles published in the Finnish- and Swedish-language press in Finland. Mentions of Tatar traders are relatively few and scattered, supporting the observation that mobile petty trade is an activity that leaves only fragmentary traces in historical sources in general. This is explained by several factors: petty trade often existed in a grey zone between the legal and illegal, it has an informal character and those engaging in it have been mobile people in the margin of society (Mikkola \& Stark 2009: 4-6; Wassholm \& Sundelin 2018b: 202). Today, digital newspaper archives offer a fast and efficient means to access these scattered pieces. The Finnish National Library's digital archive offers open access to all newspapers and journals published in Finland until 1929. The searchability of the database makes it possible to create a comprehensive overview of the situations and contexts in which the Tatar traders became visible in the Finnish press in the late nineteenth and the early twentieth centuries (Wassholm 2018: 217; Wassholm \& Sundelin 2018c: 234-235).

I have made searches in the database for various spellings and conjugations of words associated with mobile trade (Swedish gårdfarihandel; Finnish kulkukauppa) and fairs (Swe. marknad; Fin. markkina), combined with various denominations used for Tatars (for example, tatar-, tataar-, tattar-). It is important to note that the Tatars are also mentioned in alternative ways, for instance, as Orientals (Swe. österlänning; Fin. itämaalainen) or as Muslims or "Mohammedans" (Swe. muhammedan; Fin. islaminuskoinen, muhamettilainen). I have also searched for the names of individual Tatars whom the newspapers mention.

The sources pose a number of challenges with regard to source criticism. Newspaper articles usually represent the views of authorities, local merchants and newspaper editors and do not allow for making far-reaching conclusions on how the Tatars themselves perceived their trade or on their customers' attitudes towards them and their goods. The term "Tatar" is in some cases mixed with the word tattari/tattare, a derogatory term used to designate Roma in Finland (Halén 2011: 11). "Tatar" was also at times used as a generic concept for any person engaging in mobile petty trade and it does not necessarily refer to ethnic Tatars. Nevertheless, the context in most cases does reveal when an author refers to the Tatars studied in this article, as texts often include references to home region, religion, language or appearance. Tatar trade also differs from that of the Roma in scope; as Jutta Ahlbeck (2018) shows, Roma petty traders can be located within a very narrow niche.

The press played an important role in constructing notions of various phenomena and the shaping of popular opinion in late nineteenth-century Finland (Stark 2011: 40-42). An analysis of how the press depicted Tatar traders illuminates how attitudes were shaped towards them as newcomers, as well as ethnic minorities involved in petty trade in general. It also sheds new light on the livelihood of the first Tatars in Finland and their interaction with the local communities. Furthermore, it illustrates how mobile traders from Russia contributed to the ethnic heterogeneity, present in the everyday life of the Grand Duchy. This heterogeneity has been overshadowed by a long paradigm of national history writing and later methodological nationalism which strive at creating an image of a nationally and ethnically homogeneous nation. Historical research has challenged the national paradigm in the last few decades but 
the perception of Finland as a culturally and ethnically homogeneous nation in the past still persists in the public historical consciousness (Amelina \& al. 2012; Tervonen 2014; Wickström \& Wolff 2016).

In previous research, mobile petty trade of the first Tatars in Finland has attracted limited attention. I have studied relations between the early Tatar traders and local communities in Finland from the perspective of cultural encounters (Wassholm 2018). In history writing on the Tatar community in Finland, scholars such as Harry Halén and Antero Leitzinger briefly deal with the early mobile trade but in no significant depth. They rely primarily on the Tatar oral tradition and a few newspaper articles dealing with market trade (Leitzinger 2006: 86-92; 1999: 36; Halén 1999: 316-318; 2011: 3-5).

Research on the early stages of the Tatar presence in Finland has to a substantial degree relied on the community's own stories, in which the early period is often depicted as a temporary transitional phase leading to the successful businesses that Tatar merchants established a few decades later. This partly explains why research also tends to depict Tatar adaptation to Finnish society as strikingly harmonious. While Halén (2011: 4) mentions that the majority population's attitudes towards the newcomers were ambivalent and Ståhlberg (2012) maintains that the Tatars were not generally welcome, literature on the community in general conveys the community's view that the Tatars were rapidly integrated into Finnish society without conflicts and tensions (Halén 2011: 4; see also Baibulat 2004: 8, 14).

The Tatars are briefly mentioned in research on petty trade in Finland, usually in connection with the itinerant trade of the so-called "rucksack Russians" (Swe. arkangelit, laukkuryss; Fin. laukkuryssä) (Nevalainen 2016: 21-22). This group of traders came from the border regions of Arkhangelsk and Olonets in Russia and they were more numerous than the Tatars. Due to their long tradition of itinerant trade in Finland dating back to the Middle Ages, their number and their origin in East Karelia, regarded as the cradle of the Finnish nation and language, these traders occupy a more visible position in both history writing and Finnish cultural consciousness than the Tatars (Naakka-Korhonen 1988; Nevalainen 2016).

\section{PETTY TRADE AS A SPACE FOR ETHNIC ENCOUNTERS}

Tatars, Jews, Russians, artisans from our own country, sellers of textiles, fruits and vegetables were seen in a disorderly muddle in the market square. The number of mobile traders selling all sorts of small goods was conspicuously high, and they seemed to do fairly good business. (A $\mathrm{bo}$ Underrättelser 17.9.1905: 2)

This depiction of the autumn fair in Turku ( $\AA$ bo) in 1905 presents the marketplace in one of Finland's major towns as an ethnically diverse space. In this space, local customers could encounter Tatars, Russians, Karelians and Jewish traders, interact with them and purchase goods from them. At the same time, the report suggests that the pedlars were to some degree perceived as strangers, in contrast to artisans "from our own country" (Figure 1).

The Tatars were the last group of petty traders from Russia to appear in Finland. Russian traders had been present since 1809 when Finland was incorporated into the Empire. The Russian military stationed in the Grand Duchy was followed by sutlers who provided the soldiers with various material goods and many of whom soon began to trade with the civil population as well (Halén 2004; Paloheimo \& Karonen 2016). In 1858, an imperial decree allowed soldiers of the Russian army who had fulfilled their military service to settle permanently in the garrison towns 


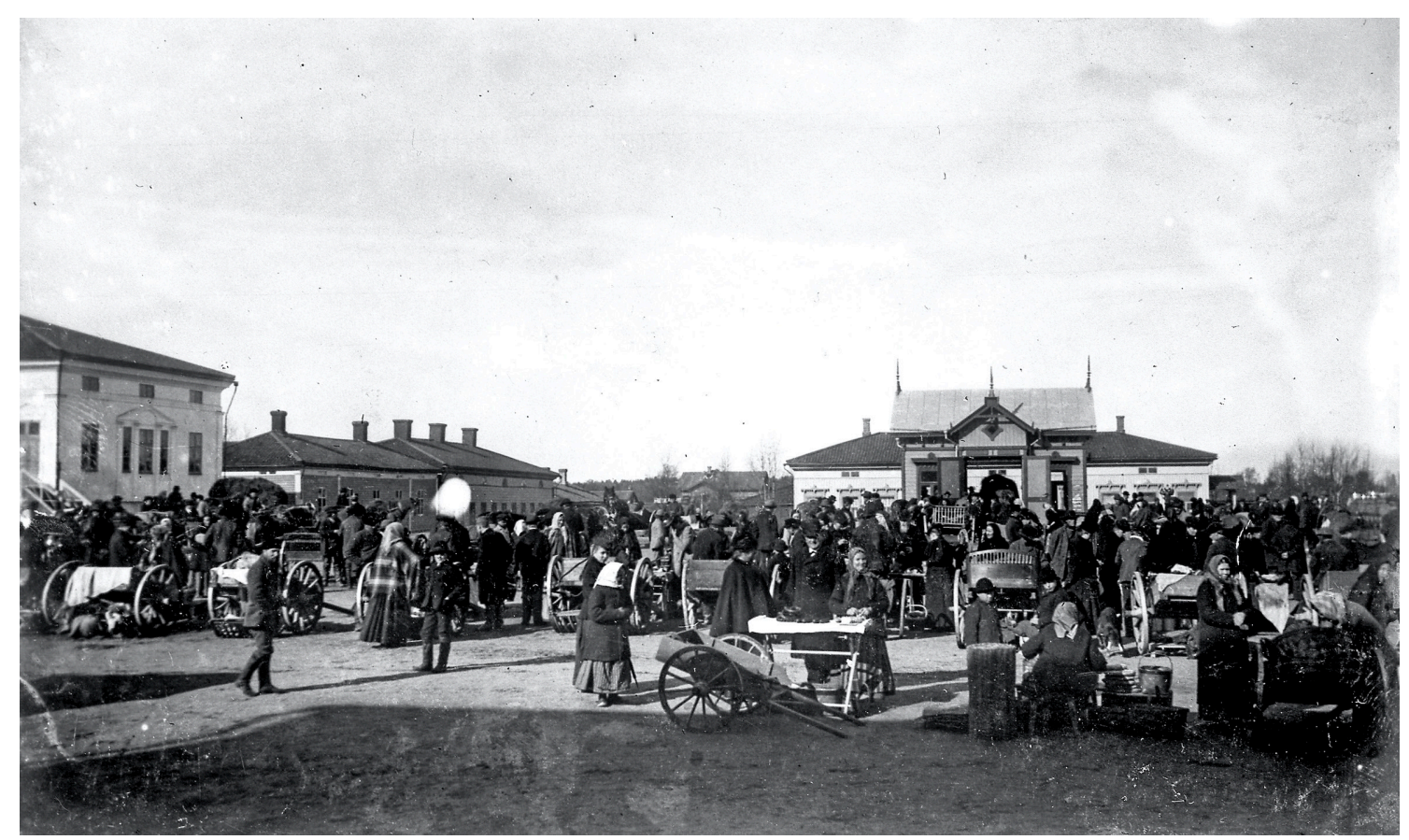

Figure 1 Market trade in Pietarsaari (Jakobstad) in 1896. The marketplace was an arena for encounters between mobile traders from "the outside" and the sedentary local community. In the 1880 s, the Finnish press noted that Tatar traders had appeared in the Grand Duchy of Finland, adding to the already existing multi-ethnic character of petty trade. Source: Pietarsaaren kaupunginmuseo (Jakobstads museum).

where they had served. These soldiers included Jews who could now for the first time legally live in Finland as civilians. A Finnish ordinance given in 1869 stated that the former soldiers had the right to support themselves by selling a limited range of minor goods, such as bread, fruits, berries, cigars, matches and various second-hand items (Wassholm 2017: 593-596; Torvinen 1989: 24-31; Ekholm 2013: 49-50).

Tatars also served in the multi-ethnic Russian army (Halén 2016: 151-175) but those who arrived in Finland in the last decades of the nineteenth century had a different background. Originating mainly in a few Mishär Tatar villages in Nizhny Novgorod province, many had previously resided in Saint Petersburg where Tatars from different regions of Russia lived since the founding of the city in 1703. In the capital, many permanently or temporarily earned their living by selling minor goods such as soap and second-hand clothes (Leitzinger 1999: 26; Khalidov 1994; Bekkin \& Ståhlberg 2016).

Tatars based in Saint Petersburg visited Viipuri (Swedish: Viborg; Russian: Vyborg) in the eastern part of the Grand Duchy of Finland possibly already in the late 1860s. According to oral tradition, the first to arrive were Samaledtin Jusupoff (later Yusuf, 1852-1930) and Alautdin Salavat (1860-1930), two soap traders who became drunk and fell asleep on a ship (Leitzinger 2006: 86, 91). These two persons, however, were still children at the end of the 1860s. Whoever the first Tatar visitors to Finland were, they maybe decided to do some peddling, but only in the 1880s did newspapers in Finland note the "procession of nomads, which in recent years has started to roam the country from town to town" (Ábo Tidning 23.9.1885: 3).

In 1882, an article in the Swedish-language newspaper Hufvudstadsbladet (5.10.1882: 2) noted that Tatars had for the first time been spotted on the Senate Square in Helsinki (Helsingfors) during the autumn fair. By the middle of the decade, observations of Tatar traders had been 
made in a dozen towns, among them Tampere (Tammerfors), Hämeenlinna (Tavastehus), Kotka, Porvoo (Borgå), Turku, Maarianhamina (Mariehamn), Uusikaupunki (Nystad), Rauma (Raumo), Pori (Björneborg) and Oulu (Uleåborg). ${ }^{1}$ In the second half of the $1880 \mathrm{~s}$, new towns were added to the list: for instance, Loviisa (Lovisa), Tammisaari (Ekenäs), Forssa and Kokkola (Gamla Karleby). A Kokkola correspondent in 1888 reported that Tatars in "immense numbers" had arrived for the winter fair (Borgåbladet 17.19.1888: 2; Ekenäs Notisblad 20.9.1887: 3; Aura 12.12.1888: 3; Norra Posten 31.10.1888: 3). Later Tatars would trade as far north as Kemi and Tornio (Torneå) (Halén 1999: 317; Leitzinger 2006: 86, 91).

The emergence of Tatar traders in Finland can be explained by two contributing factors. The first was the expanding economy from the 1860s which spurred consumption. Simultaneously, the population increased as a consequence of improvements in health care, medicine and living conditions. The economic growth was partly the result of the liberalization of the economy contributing to industrial development. Particularly strong was the forestry industry; it experienced a veritable boom due to increased global demand. The economic acceleration provided the lower classes of society with new work opportunities and higher salaries, allowing them to also spend money on consumer goods (Haapala 2007: 47-50; Mikkola \& Stark 2009: 4). In territorially vast but sparsely populated regions, mobile petty traders have traditionally played an important role in answering to growing demands and offering consumer goods to the lower classes of society (Wassholm \& Sundelin 2018a: 3). In the case of Finland, traders from the Russian Empire took a leading role in this process.

The second factor which explains the appearance of Tatars was the development of communications, a prerequisite for increased mobility of both traders and goods. Most towns Tatar traders frequented were situated either on the coast or along the railway lines. Newspapers contain evidence that Tatars used regular transport to travel to fairs around the Grand Duchy. At the same time as the press started to note that Tatars were trading in Finland, Tatar names are found on passenger lists of regular steamers. In August 1883, newspapers feature passenger lists which mention that eight Tatars had arrived in Turku on the steamer A It seems reasonable to assume that it was the same group of Tatars who for a few weeks were reported as having arrived on steamers to visit the fairs in the nearby towns of Pori and Rauma (Åbo Posten 21.8.1883: 4; Abo Tidning 29.9.1883: 1; Aura 2.10.1883: 3).

Traders travelling by ship were also noted in a number of other contexts. In the spring of 1886, a local newspaper in Kotka mentioned that Tatar traders were expected to arrive in town in considerable numbers as soon as the navigation season opened, just as they did in previous years (Kotka 24.4.1886: 3). In 1896, a steamer departed from Turku, transporting mainly Tatar and Jewish traders who were headed for the fair in Salo with their goods ( $A b o$ Underrättelser 12.5.1896: 2). From Turku, Tatars also travelled to Maarianhamina in the Åland Islands, only accessible by sea; in 1896 the trip was made on board the steamship $S / S$ Bore (Ábo Tidning 23.9.1885: 3; 5.10.1892: 3; 23.9.1899; Åland 26.9.1896: 2).

1 The first mentions I have found of Tatar traders in Finnish towns include, in chronological order, Tampere (Tammerfors Aftonblad 8.9.1882: 2); Hämeenlinna (Ảbo Underrättelser 29.9.1882); Helsinki (Hufvudstadsbladet 5.10.1882: 2); Oulu (Kaiku 28.7.1883: 2); Pori (Satakunta 12.9.1883: 3); Turku (Tammerfors Aftonblad 24.9.1883: 2); Porvoo (Borgåbladet 10.10.1883: 1); Kotka (Kotka 1.12.1883: 2); Maarianhamina (Åbo Tidning 23.9.1885: 3); Uusikaupunki (Åbo Tidning 23.9.1885: 3); Rauma (Aura 2.10.1883: 3); Pori (Satakunta 12.9.1883: 3). 
The mobility of people and goods was facilitated by the expansion of the railway network, especially after the Finnish network was connected to the Russian one. The line between Riihimäki and Saint Petersburg was opened in 1870 (Jutikkala 1957: 337; Hjerppe 1989: 81-82). This was significant for the Tatars, who moved between Finland and their home region south of Nizhny Novgorod more than a thousand kilometres away. The railway made it easier to maintain networks and family connections between the place of origin and the destination, a typical trait of early stages of migratory movement (Light, Bhachu \& Karageorgis 2004: 25). The distance made the Tatars more dependent on modern communications than for instance the "rucksack Russians" who lived in the border region of Finland and traditionally travelled on foot. Moreover, the railway was essential for the transportation of goods. The Tatars acquired their merchandise mainly in Saint Petersburg and other large towns in Russia. Also Nizhny Novgorod was a major trading town and it hosted one of the Empire's most important fairs (Lincoln Fitzpatrick 1990). The railway played an important role for the expansion of Tatar trade within the borders of Finland, too: in 1886 the railway reached Oulu and in $1893 \mathrm{Kemi}$ and Tornio, the two northernmost towns where Tatar traders are mentioned (Halén 1999: 317; Leitzinger 2006: 86, 91).

The patterns of mobility and distribution were altered towards the end of the nineteenth century when Tatar traders started to settle in Finland permanently. Some of them established shops in towns and employed other Tatars to sell and distribute their goods. From that time on, mostly young Tatar men could be seen carrying goods on bikes in the countryside as well (Ståhlberg 2012). Trading spaces such as fairs, market squares and streets - and in the case of itinerant trade also private homes - were arenas for cultural encounters between mobile traders from the "outside" and sedentary local communities (Rosander 1980: 9; Storå 1989: 34; 1991: 74; Wassholm \& Sundelin 2018a: 3). Although Tatar petty traders in Finland were few in absolute numbers, never exceeding a few hundred in the late nineteenth century, many Finns came into contact with them due to their mobile trade.

In their seminal works on cross-cultural and mobile trade, Philip D. Curtin (1984: 1) and Laurence Fontaine (1996: 5) maintain that trading encounters between people of different geographic, social and cultural backgrounds typically evoke ambivalent sentiments. The external influences that such encounters contribute gave an impetus for change in the local communities. Mobile traders with everyday practices which differ from those of sedentary societies have typically been viewed as unpredictable and possibly dangerous "strangers". We can assume that both of these mechanisms played a role in the encounters between mobile Tatar traders and the local communities in late nineteenth-century Finland.

\section{STEREOTYPICAL DEPICTIONS OF TRADING PRACTICES AND GOODS}

\footnotetext{
They deceive people with their outstanding trading skills and their worthless goods. If that is not enough, they utilize any means needed to achieve this. Last night, a number of Tatars were spotted peddling their goods to a decent farmer. When he refused to buy, a Tatar - in their customary manner - started to slander him for being poor. And he did not content himself with that; he even gave the farmer a clip round the ear. (Tampere 6.9.1884: 3)
}

This quotation exemplifies how authors usually depicted Tatar trading practices and their interaction with local customers in Finland. The description from the autumn fair in Tampere in 1884 followed a highly stereotypical pattern: the trader was described as luring a simple- 
minded customer into paying an excessive amount of money for a worthless item he or she did not need. In this particular case, when the customer refused to buy it, the trader became insolent and started to offend and even physically abuse the Finn. The author of the article noted that the Tatar was arrested but complained that it was not easy to get such traders prosecuted if their travel documents were in order.

Authors of newspaper articles often noted the Tatar traders in connection with their trading practices, characterizing them by a few main traits: the Tatar traders were described as being excessively impudent, intrusive and shameless in their interaction with their potential customers (Kotka 25.7.1885: 3; Aura 10.11.1885: 3; Aamulehti 26.2.1884: 2; Borgå Nya Tidning 30.6.1893: 3; Wasa Nyheter 28.1.1898: 3). An article in Hufvudstadsbladet (1.10.1886:2) mentioned that Tatar trading practices included a "peculiar habit to force their goods down the customer's throat". Their trading practices were also typified in terms of continual and eager haggling - a typical trait of petty trade (Geertz 1963: 32-33; Ekholm 2013: 91). While bargaining was common in petty trade in general, Finnish newspapers in the late nineteenth century often mentioned it in connection with foreign traders. Various groups of traders were placed in a hierarchy where Jews and Tatars were depicted as the most resolute bargainers.

Tatar intrusiveness and their insistent trading practices appeared to be problematic for Finns. Allegedly inexperienced local customers from the lower classes of society, unaccustomed to these practices, ran the risk of being swindled. The result of the aggressive bargaining was that customers paid excessive prices for the merchandise, sometimes up to ten times more than they were worth (Folkwännen 2.7.1883: 2-3; Norra Posten 31.10.1888: 3; Turun Lehti 22.9.1888: 2). Several authors felt an obligation to warn consumers at the marketplace against dealing with Tatars. Their potentially deceptive practices were described with a rhetoric that follows a highly stereotypical pattern for depictions of the relations between customers belonging to the lower classes and ethnified non-local traders across regions and historical epochs (see Mitchell 2014: 62-63). At the same time, the newspaper rhetoric reflected a general derogatory attitude towards the low-class consumers who were generally described as simple and demoralized.

Stereotypical attitudes were also projected onto the Tatars' goods; among them cloths, furs and carpets were the most important (Ståhlberg 2012). In addition to these, newspapers mentioned a variety of other items such as tablecloths, napkins, towels, clothes, slippers, horse equipment, porcelain, toys and candlesticks made of brass (Nystads Tidning 5.2.1896: 1; Kotka 25.7.1885: 3; Kristinestads Tidning 7.10.1896: 2; 4.2.1899: 2; Norra Posten 31.10.1888: 3; Hufvudstadsbladet 1.10.1886:2; Vestra Nyland 13.10.1893: 2; Fredrikshamns Tidning 7.10.1896: 2; Åbo Underrättelser 28.9.1908: 2; Wiborgs Nyheter 6.9.1909). In 1885, a newspaper noted that the first Tatar traders in Kotka had primarily traded cloth. Observing that the local authorities did not interfere with their activities, the Tatars quickly began to expand their supply of goods. After a few years they allegedly sold "almost everything" in Finland (Aura 10.11.1885: 3). In the newspapers, the goods were depicted as being poor in quality, following a stereotypical rhetoric compatible with the depictions of their trading practices: the Tatars were said to peddle with "all sorts of worthless rubbish" (Aura 10.11.1885: 3; Leitzinger 2006: 91; Halén 1999: 316-317). The ideology and preconceived notions behind the rhetoric prevent us from drawing any far-reaching conclusions on the actual quality of the goods or the meanings they held for the customers. However, the growing number of Tatar traders in Finland in the last decades of the nineteenth century suggests that there was a real demand for their merchandise. 


\section{SPACE AND TACTICS: CHALLENGING LAWS AND STRETCHING BORDERS}

Tatars have arrived at the fair in great numbers, peddling with legal but worthless goods. We want to remind all parties of why they have judged it suitable to peddle from door to door, treating the residents in a most shameless manner. (Aamulehti 26.2.1884: 2)

The authorities at different levels of the administration in Finland - local, regional and national - had an economic and social interest in controlling trade. Legislators, the police and local authorities attempted to regulate rights, defining who could trade with specific goods at certain places and times. Fairs in particular put large numbers of people in motion and gathered all strata of society in one place at a specific time. Fairs and markets were therefore regarded as spaces where disturbances and problems could potentially arise (van den Heuvel 2012: 126). In line with Michel de Certeau's theory of everyday practices, the authorities' attempts to control trading places through regulation can be regarded as a strategy to exercise formal power. The formal power did not stop the traders and customers from using possibilities to exercise their own power. They did so through informal everyday practices, conscious or unconscious, which can be analyzed through the concept of tactics (de Certeau 1984; Koivunen \& Syrjämaa 2011: 51-52).

Petty trade often takes place in the greyzone between the legal and illegal. Inconsistencies between jurisdiction and its application are common, while laws and regulations at local, regional and national levels can be contradictory. Civil servants in Finland would sometimes interpret laws, decrees and regulations inconsistently, for instance granting rights to peddle or open a business to individuals who formally lacked such legal rights (see for example Lindberg 2018; Bredefeldt 2008). The authorities also commonly overlooked even openly illicit trade. Finnish law did not allow persons without citizenship in the Grand Duchy the right to engage in itinerary trade and even for Finnish citizens it was heavily restricted. The Tatars, although Russian subjects like the Finns, could not acquire citizenship rights in Finland until after its independence in 1917. While they were formally not allowed to engage in mobile trade, in many cases the authorities apparently accepted the Tatars much in the same way as they did with the "rucksack Russians" (Nevalainen 2016; Wassholm \& Sundelin 2018a). Tatars had the formal right to trade at urban market squares and fairs under provision that they were equipped with valid travel documents and paid the regular trading fees to the town administration. The shifting line between legal and illicit trade - and above all the tendency to tolerate even clear cases of the latter - gave the traders an opportunity to challenge laws and test the limits of regulations.

The uncertainties surrounding the legal status of the Tatar traders soon surfaced in the press. In the early stages, questions about their right to peddle in the Grand Duchy were posed openly, reflecting the confusion surrounding regulations. Critics were aware of the fact that the Tatar trade was illegal and they urged the authorities to take responsibility and restrain it. This illustrates both the authorities' attitudes and the traders' tactics or more precisely how newspapers depict their alleged tactics.

One way of challenging regulations was to peddle in places where it was not allowed. Tatars sold their goods in rural areas although it was forbidden by laws and regulations. Most of the time no consequences followed but there were exceptions. Occasionally, rural police chiefs would refuse to overlook the illicit trade and arrest Tatars and other pedlars who lacked citizenship rights in the Grand Duchy or valid documents. If the charges were found to be solid, the penalty was usually confiscation of goods and a fine; short paragraphs in newspapers occasionally informed the readers about Tatar traders who had been arrested (Hämeen 
Sanomat 7.12.1886: 2; Päivälehti 4.5.1898: 4; Wasa Tidning 7.4.1898: 2; Kotka 14.4.1898: 3; Wiipuri 1.1.1911: 3). However, arrest and indictment were more the exception than the rule (Nevalainen 2016: 119-120; Wassholm \& Sundelin 2018a: 9).

The question of illicit trade was not seldom raised by local merchants and craftsmen who accused the authorities of ignoring their duties as guardians of law and order. Tatars were depicted as unjust competitors to local entrepreneurs and the authorities were urged to take urgent measures. Such accusations were expressed in editorial letters usually signed by anonymous collectives of "merchants and craftsmen". The letters might have been fabricated by editors who were dissatisfied with the local authorities, or written by a single particularly active and determined merchant in the name of a collective. Whatever the case, the letters offer insight into the relations between the mobile and the settled traders.

In Tammisaari, an editorial letter published in the local newspaper Vestra Nyland in 1892 asked how long the local authorities intended to allow Tatars to walk from house to house selling their "Russian rags and cloths". This activity is portrayed as a "gross injustice"; the Tatars who did not pay taxes or other trading fees in the Grand Duchy were allowed to peddle the same goods as local entrepreneurs in spaces where trade was forbidden for Tatars (Vestra Nyland 23.9.1892: 3). Merchants in Turku noted the same "problem" in 1898 as did a group of merchants in Kemi. The latter published a letter to the editor in the local newspaper where they stated that it was unfair that the local authorities allowed "foreigners" (Tatars) to trade in town as it caused financial losses to local merchants. Allegedly, a Tatar residing in the house of a certain customs official named Pietilä had traded in the town for years, at times being joined by other Tatars (Åbo Underrättelser 10.12.1898: 2; Perä-Pohjolainen 20.8.1898: 4).

Relations between local entrepreneurs and Tatars were particularly strained in Kotka in the southeast; in 1885 the merchants complained about Tatar pedlars who had "flooded the town" (Kotka 25.7.1885: 3). In an editorial letter published in the local newspaper, they maintained that peddling Tatars were more numerous in Kotka than in any other town in the Grand Duchy. The Tatars caused a great deal of harm to the local entrepreneurs with their illicit trade (Kotkan Sanomat 29.11.1892: 2; Kotka 1.12.1892: 2). By this time, many Tatars had already permanently settled in Kotka. The merchants primarily targeted the Public Prosecutor and the town magistrate with their criticism. According to the accusations, the authorities had refrained from taking action against Tatar trade in forbidden spaces despite the fact that it took place right under their noses. The authorities were required to expel the "cheating salesmen" from town as had been done in the neighbouring towns of Hamina (Fredrikshamn) and Loviisa (Kotka 25.7.1885: 3; 24.4.1886: 3).

The conflict in Kotka continued into the 1890s. Local "merchants and craftsmen" repeatedly accused the town authorities of allowing Tatars to trade without permission in the market square, streets and private homes. At one stage, the traders even threatened to take the law into their own hands if the authorities refused to act. It seems that the town authorities temporarily did intensify surveillance and in 1886 peddling was prohibited. The effects were short-lived, however. In the spring of 1888 , the merchants repeated their complaint because the Tatars had returned and continued their trade. The difference was that they now did not trade in open spaces where they could be caught. The local entrepreneurs once again demanded that the authorities make the Tatars liable if they refused to abide by regulations rather than treating them with "indifference and understating" as the authorities had done previously (Kotka 24.4.1886: 3; 9.6.1888: $3 ; 1.12 .1892: 2$ ). 
Each and every one of us has had the opportunity to read in the press that those vagrants' goods have now and again been confiscated and that the pedlars have been fined. Unfortunately, the responsible authorities in our town have not succeeded in confiscating the Tatars' goods, although they have engaged in illicit trade in Kotka for several years. We are not sure whether the reason for this is that the Tatars are so skilful at hiding in times of trouble or the negligence of the authorities. (Kotkan Sanomat 29.11.1892: 2)

Another way for the traders to challenge specifically spatial restrictions was the use of space in the market square; an example can be found in a newspaper report from the coastal town of Porvoo in 1893. The author complained about a group of Tatars who had arrived to sell their goods at the fair. They paid the regular fee for a stand in the square but they did not restrict their trade to that specific place. Instead, they were described as peddling in all corners of the fair ground, actively forcing their "Russian cloths and knick-knacks" upon potential customers (Borgå Nya Tidning 30.6.1893: 3).

In other examples, Tatars were accused of occupying the best trading places in market squares by dishonest means. An example of such conduct is mentioned in Hufvudstadsbladet in 1886. A group of Tatars had paid two Finnish marks for the right to sell baskets at a small stand during the autumn fair in Helsinki. In practice, they occupied a considerably larger space for which they should have paid at least twenty marks (Hufvudstadsbladet 1.10.1886: 2). During the fair, Tatars were also accused of selling their goods in the streets or door to door which was a prohibited practice (Vestra Nyland 23.9.1892: 3; Turun Lehti 25.8.1894: 2-3).

An analysis of how Tatar traders were depicted as challenging regulations and spatial restrictions illustrates how the traders could create their own space in relation to formal regulations, but also the ways in which the interests of local merchants and traders from the outside stood in conflict with them. Such conflicts are typical in situations where established merchants feel that their business is threatened, especially when newcomers start to expand their trade in such a way that it encroaches on the local merchants' territories. In such contexts, it is common for the merchants to react and take joint measures to counteract traders from the outside. An example of this can be found in Turku in the 1880s. Jews who were only allowed to trade a limited range of minor goods, primarily second-hand clothes, challenged the regulations. Only when the authorities allowed Jews to establish shops where they sold ready-made clothes did the local merchants react (Wassholm 2017: 609-615; see also Alanen 1957: 128; Carlsson 2004: 139-141; Hammarström 2016: 28).

\section{THE FAIR AS A THREATENING SPACE}

Beware of Tatars! It is well known that a group of Tatars dressed in untidy kaftans, carrying their filthy bags, roam our town. Often they half forcibly push their way into private houses peddling clothes. As their goods originate in Russia and are transported here from Saint Petersburg - without any precautions whatsoever - seeds of cholera can easily be transported here with their goods. (Turun Lehti 25.8.1894: 2-3)

This quotation depicts some potential threats and dangers which were at times associated with the fair or the marketplace as a space. In this particular context, the threat is connected with a mobile way of life representing "otherness" from the perspective of sedentary societies and used to create and sustain mechanisms of caution and fear. Such mechanisms are often activated in situations where certain emotions can be associated with a tangible threat (Häkkinen 2005: 226-227). 
In the last decade of the nineteenth century and the first decade of the twentieth century, Finnish authorities feared that cholera epidemics would spread from Russia to Finland. The Grand Duchy had experienced periodic cholera epidemics since the 1830s and in 1853 and 1871 hundreds of people perished from the disease. In 1892, when news about the outbreak of a large-scale cholera epidemic in Russia reached Finland, the authorities immediately took action to prevent potential sources of cholera from crossing the border (Pesonen 1980: 382-383; Nygård 2004: 214-216). In the years 1892, 1893 and 1894, the local and central authorities even restricted or cancelled fairs. In 1892, a decree issued by the Senate of the Grand Duchy cancelled the autumn fairs in Viipuri, Kuopio, Mikkeli (St Michel), Hämeenlinna and Tampere (Vestra Nyland 9.9.1892: 2).

The health board of Turku also petitioned the Senate to cancel the autumn fair but was turned down. As the autumn fair drew closer, the local newspapers reported that Tatars, Russians and other traders from cholera-infested regions in Russia had arrived as usual in great numbers. They brought with them leather goods, furs and textiles which were feared to contain contagious agents. Authors demanded that the items should not be allowed into town, at least not until they had been thoroughly disinfected (Åbo Underrättelser 14.9.1892: 2).

The health board of Turku then published announcements in the local newspapers, urging the townspeople to avoid contact with "strangers, especially mobile traders". Potential customers were also warned that the Tatars did not respect the spatial restrictions of the police regulations; formally they only had permission to trade in the market square on official fair days but in practice they continued to peddle "from house to house". Considering the threat of cholera, it was of utmost importance that local residents refuse to let Tatars into their homes and that the police guard law and order (Åbo Underrättelser 14.9.1892: 2).

Similar announcements were issued in several towns in Finland in the following years. In 1893, cholera again broke out in Russia. From Hämeenlinna where the autumn fair in the preceding year had been cancelled, it was reported that relatively few sellers had arrived in town with the exception of a substantial number of Tatars "hoping, it seems, to do lucrative affairs". The town magistrate urged visitors and townspeople to avoid buying anything from Tatars and other "strangers" and to immediately inform the police if Tatars attempted to enter private homes. Furthermore, it was proposed that doctors should examine the Tatar traders while they stayed in town (Hämäläinen 23.9.1893: 1; 27.9.1893: 3). The same year, the health board in Tammisaari also prepared for the upcoming autumn fair by warning the local dwellers to keep away from "Russian and Tatar" petty traders who were expected to arrive as usual. They had brought with them goods of leather and linen acquired from cholera regions (Vestra Nyland 3.10.1893: 2; Ekenäs Tidning 7.10.1893: 2). The threat continued to be imminent into the early twentieth century when epidemics still occurred in Russia. At least in the years 1908 and 1910, fairs in Finland were still restricted due to the risk of cholera.

As the spread of the disease was associated with poor hygiene, depictions of Tatar traders became extremely negative and associated with dirt as exemplified in the following quote from 1892: "Ragged Tatars sell dirty textiles and clothes, touched by a hundred pairs of hands before the hundredth and first customer buys a piece of them" (Östra Finland 7.9.1892: 3). The criticism was not solely directed at sellers from Russia; customers who bought goods from these traders were also depicted as immoral and irresponsible: 
It is also questionable whether people who bargain with Tatars have an appropriate idea of tidiness. It should be common knowledge that cleanliness is a concept unknown to the Tatars. Even a quick glance at the Tatars and the rags in which they wrap their goods is enough to confirm this fact. (Kotka 28.2.1895: 2).

The association of the traders and their customers with dirt follows a stereotypical pattern. Dirt - real or imagined - was typically associated with "the Other" in late nineteenth-century society and commonly used to justify exclusionary practices and ethnic class distinctions (Häkkinen 2005: 226-227; Masquelier 2005: 6-7). In this specific context, an ethnic distinction was made in relation to the Tatars and a class distinction in relation to the lower strata of society.

In connection with the cholera threat, the fairs were depicted as threatening spaces in two respects. First, the trading space as such represented a threat because it attracted people from various regions who were difficult to control. Second, Tatars and other mobile traders were described as particularly threatening because they brought with them merchandise that they might have obtained in cholera-infested regions. While all traders from Russia were viewed with suspicion in this regard it seems that Tatars were particularly targeted. This might be explained by the fact that cholera in Russia often spread in settlements along the large rivers, including the Volga River where Nizhny Novgorod is situated. This city was often mentioned in lists of towns badly hit by cholera and its important fair was restricted due to epidemics (Rauman Lehti 17.8.1892).

As the Tatar home region was known to be close to Nizhny Novgorod and the Tatars procured part of their goods from there, they were depicted as a particular threat in Finland. In a sense Tatars became the scapegoats when fear arose around epidemics. Seeing outsiders as the source of epidemics is typical; in Italy such fears were projected onto Roma and Jews while the British in India ascribed the spreading of cholera to the "dirty" local population (Hayes 2005: 349).

\section{CONCLUSIONS}

I have examined depictions of Tatar petty traders in the Grand Duchy of Finland in the late nineteenth century, using the concepts of space and tactics as analytical tools. In this period, the expanding economy granted the lower strata of Finnish society higher income which resulted in increased demand for consumer goods. The needs were partly answered by mobile traders, many of whom originated in Russia, and petty trade formed an arena for encounters between traders and sedentary local communities. Although the Tatars were few in number, many Finns encountered and interacted with them since the 1880s.

The available newspaper sources convey a highly stereotypical view of Tatar trade but nevertheless shed light on the contexts in which the Tatars attracted the attention of the local society and authorities. Often Tatars were noticed in trading places due to their selling practices which deviated from the usual. Authors argued that Tatar trading practices were intrusive and characterized by insistent haggling, eager persuasion and even scolding of the customer. In the view of the authorities, this gave a reason to warn the "inexperienced" local customers against being swindled. A corresponding stereotypical and derogatory rhetoric was also used to describe the customers. They were depicted as vain, naïve and easily deceived. The rhetoric follows a stereotypical pattern which can be identified in depictions of ethnified traders and consumers of the lower strata of society in other times and regions.

The concept of space can be applied to analyse the Tatar trade from several perspectives. The early Tatar traders were mobile over a vast territory in Finland and Russia and in some 
contexts this affected attitudes towards them negatively, for instance in the 1890 s when cholera epidemics occurred in Russia. Authorities tried to stop the traders from entering towns in Finland and the fairs were depicted as highly threatening spaces.

Further, the use of space played a role in depictions of Tatar traders in marketplaces. The authorities used their formal power to regulate and control trade while traders and customers often challenged this regulation through their everyday practices and more specifically through informal tactics. The newspaper materials suggest that Tatar traders often defied formal regulation, bargaining in spaces where trade was not allowed for instance in rural regions while travelling from town to town, in streets outside the restricted market area and even in private houses. In the actual market space, they refused to stay in the place they had paid for or tried to get hold of the best trading spaces by dishonest means.

The depictions of Tatar traders in the press follow certain patterns, primarily reflecting the attitudes of the authorities, journalists and local merchants towards mobile traders from outside the borders of Finland. Although the sources do not offer access into the views of the traders themselves or their customers, they do offer new insights into the role of ethnified petty trade as an everyday practice in the late nineteenth-century society in Finland. As various forms of mobile small-scale trade have left relatively few traces in the historical sources, digital newspaper databases offer new possibilities to examine various aspects of the relations between itinerant traders and local communities.

This analysis complements history writing about the Tatar community in Finland which has tended to stress the seamless and conflict-free integration of Tatars into Finnish society. While we might assume that relations between Tatar traders and the communities they encountered in Finland were often neutral, this analysis illustrates contexts where petty trade could cause tensions. These kinds of patterns can also be applied to contemporary society where people become mobile in search of livelihood and where informal petty trade for many newcomers opens the door to a new existence in another environment.

\section{REFERENCES}

\section{Newspapers}

Aamulehti 26.2.1884

Abo Posten 21.8.1883

Ábo Tidning 29.9.1883; 23.9.1885; 5.10.1892; 23.9.1899

Ábo Underrättelser 29.9.1882; 14.9.1892; 12.5.1896; 10.12.1898; 17.9.1905; 28.9.1908

Aland 26.9.1896

Aura $2.10 .1883 ; 10.11 .1885 ; 12.12 .1888$

Borgå Nya Tidning 30.6.1893

Borgåbladet 10.10.1883; 17.19.1888

Ekenäs Notisblad 20.9.1887

Ekenäs Tidning 7.10.1893

Folkwännen 2.7.1883

Fredrikshamns Tidning 7.10.1896

Hämäläinen 23.9.1893; 27.9.1893

Hämeen Sanomat 7.12.1886

Hufvudstadsbladet 5.10.1882; 1.10.1886

Kaiku 28.7.1883 
Kotka $1.12 .1883 ; 25.7 .1885 ; 24.4 .1886 ; 9.6 .1888 ; 1.12 .1892 ; 28.2 .1895 ; 14.4 .1898$

Kotkan Sanomat 29.11.1892

Kristinestads Tidning 7.10.1896; 4.2.1899

Norra Posten 31.10.1888

Nystads Tidning 5.2.1896

Östra Finland 7.9.1892

Päivälehti 4.5.1898

Perä-Pohjolainen 20.8.1898

Rauman Lehti 17.8.1892

Satakunta 12.9.1883

Tammerfors Aftonblad 8.9.1882; 24.9.1883

Tampere 6.9.1884

Turun Lehti 22.9.1888; 25.8.1894

Vestra Nyland 9.9.1892; 23.9.1892; 3.10.1893; 13.10 .1893

Wasa Nyheter 28.1.1898

Wasa Tidning 7.4.1898

Wiborgs Nyheter 6.9.1909

Wiipuri 1.1.1911

\section{Literature}

Ahlbeck, Jutta 2018. Tingens paria: Romers gårdfarihandel och artefakters betydelse under första hälften av 1900talet. Historisk Tidskrift för Finland 103(2): 262-294.

Alanen, Aulis J. 1957. Suomen maakaupan historia. Helsinki: Kauppiaitten kustannus.

Amelina, Anna, Devrimsel D. Nergiz, Thomas Faist \& Nina Glick Schiller (eds) 2012. Beyond Methodological Nationalism: Research Methodologies for Cross-Border Studies. NY: Routledge.

Baibulat, Muazzez 2004. Tampereen Islamilainen Seurakunta: juuret ja historia. Tampere İslam Mahallesi: Nigizı ve tariht. The Tampere Islamic Congregation: The Roots and History. Tampere: Tampereen Islamilainen Seurakunta.

Bekrin, Renat \& Sabira StÅhlberg 2016. Saint Petersburg. In: I. Svanberg \& D. Westerlund (eds), Muslim Tatar Minorities in the Baltic Sea Region (Muslim Minorities Series 20): 67-85. Leiden: Brill.

Bredefeldt, Rita 2008. Judiskt liv i Stockholm och Norden: Ekonomi, identitet och assimilering 1850-1930. Stockholm: Stockholmia Förlag.

CARlsSon, Carl Henrik 2004. Medborgarskap och diskriminering: Östjudar och andra invandrare i Sverige 18601920. (Studia Historica Upsaliensia 215) Uppsala: Uppsala Universitet.

de Certeau, Michel 1984. The Practice of Everyday Life. Berkeley, Los Angeles: UC Press.

CuRTin, Philip D. 1984. Cross-Cultural Trade in World History. Cambridge: CUP.

Екноцм, Laura Katarina 2013. Boundaries of an Urban Minority: The Helsinki Jewish Community from the End of Imperial Russia until the 1970s. (Publications of the Department of Political and Economic Studies) Helsinki: University of Helsinki.

Fontaine, Laurence 1996. History of Pedlars in Europe. Cambridge: Polity Press.

Geertz, Clifford 1963. Peddlers and Princes: Social Development and Economic Change in Two Indonesian Towns. Chicago: UCP.

Haapala, Pertti 2007. Kun kaikki alkoi liikkua. In: P. Haapala \& K. Häggman (eds), Suomalaisen arjen historia 3: Modernin Suomen synty: 47-74. Helsinki: Weilin \& Göös.

HalÉn, Harry 1999. Suomen tataarit. In: M. LöYtÖNEn \& L. Kolbe (eds), Suomi: Maa, kansa, kulttuurit (SKST 753): 315-332. Helsinki: Suomalaisen Kirjallisuuden Seura.

HALÉn, Harry 2004. Viaporin marketentteja ja muita kauppiaita 1808-1918. (Unholan aitta 19) Helsinki: Tuohivirsu.

HalÉn, Harry 2011. Suomen tataarit. In: K. Bedretdin (ed.), Tugan tel: Kirjoituksia Suomen tataareista (Suomen Itämaisen Seuran suomenkielisiä julkaisuja 39): 1-26. Helsinki: The Finnish Oriental Society. 
HALÉN, Harry 2016. De ryska muslimsoldaterna som den finländska tatarminoritetens förtrupp. In: M. WICKSTRÖM \& C. WolfF (eds), Mångkulturalitet och minoriteter i Finland under tre sekel (SSLF 803): 151-175. Helsingfors: Svenska litteratursällskapet i Finland.

Hammarström, Per 2016. 'Judar öfversvämma landet'. Den judiska gårdfarihandeln i Kungl. Maj:ts befallningshavandes femårsberättelser 1865-1905. In: E. Nydahl \& J. HARVARD (eds), Den nya staten: Ideologi och samhällsförändring kring sekelskiftet 1900: 25-50. Lund: Nordic Academic Press.

Harviainen, Tapani 2001. The Islamic Congregation of Tatars in Finland-Acknowledged from 1925 on (Proceedings of the Finnish Institute in the Middle East 2001(3)): 1-8. Vantaa: Suomen Lähi-idän instituutin säätiö.

HaYes, Jo N. 2005. Epidemics and Pandemics: Their Impacts on Human History. Santa Barbara, CA: ABC-CLIO.

van Den Heuvel, Danielle 2012. Selling in the Shadows: Peddlers and Hawkers in Early Modern Europe. In: M. VAN DER Linden \& L. LuCASSEN (eds), Working on Labor: Essays in Honor of Jan Lucassen (Studies in Global Social History 9): 125-151. Leiden: Brill.

HJerppe, Riitta 1989. The Finnish Economy 1860-1985: Growth and Structural Change. (Studies on Finland's Economic Growth 13) Helsinki: Bank of Finland.

HäKKINEN, Antti 2005. Kiertäminen, kulkeminen ja muukalaisuuden kohtaaminen 1800-luvun lopun ja 1900-luvun alun maalaisyhteisössä. In: A. Häkninen, P. Pulma \& M. Tervonen (eds), Vieraat kulkijat - tutut talot: Näkökulmia etnisyyden ja köyhyyden historiaan Suomessa (Historiallinen Arkisto 120): 225-262. Helsinki: Suomalaisen Kirjallisuuden Seura.

JutiKKalA, Eino 1957. Turun kaupungin historia 1856-1917, I. Turku: Turun sanomalehti ja kirjapaino osakeyhtiö.

Khalidov, Anas B. 1994. The History of Islam in St Petersburg. Religion, State and Society 22(4): 245-249.

KLINGE, Matti 1984. Venäläisyydestä Suomessa. In: P. Kurkinen (ed.), Venäläiset Suomessa 1809-1917 (Historiallinen arkisto 83): 11-20. Helsinki: Suomen Historiallinen Seura.

Kotvunen, Leila \& Taina SYrJämaA 2011. Tekijöiden ja yleisöjen valta näyttelyissä: Antonio Gramscin ja Michel de Certeaun teoriat epävirallisen vallan tutkimuksessa. In: I. AALto, L. BoXBERG, U. IJÄs \& H. PAALUMÄKI (eds), Vallan teoriat historiantutkimuksessa: 40-60. Turku: Turun historiallinen yhdistys.

Leitzinger, Antero 1999. Tataarit Suomessa. In: T. Sakaranaho \& H. Pesonen (eds), Muslimit Suomessa: 25-58. Helsinki: Yliopistopaino.

LeITZINGER, Antero 2006. Suomen tataarit: vuosina 1868-1944 muodostuneen muslimiyhteisön menestystarina. Helsinki: East-West Books.

Light, Ivan, Parminder BHACHU \& Stavros KARAGEORgIS 2004. Immigrant Networks and Immigrant Entrepreneurship. In: I. Light \& P. BACHU (eds), Immigration and Entrepreneurship: Culture, Capital and Ethnic Networks: 25-49. New Brunswick: Transaction Publishers.

Lincoln FitzPatrick, Anne 1990. The Great Russian Fair: Nizhnii Novgorod 1840-1890. London: MacMillan.

LINDBERG, Hanna 2018. "I händerna på arkangeliter, judar och andra schackrare": Debatten om gårdfarihandel på Finlands lantdag 1877-1878. Historisk Tidskrift för Finland 103(2): 205-230.

Masquelier, Adeline 2005. Dirt, Undress, and Difference: An Introduction. In: A. Masquelier (ed.), Dirt, Undress, and Difference: Critical Perspectives on the Body's Surface: 1-34. Bloomington: IU Press.

Mikкola, Kati \& Laura STARK 2009. Himotut ja halveksitut kulutustarvikkeet: uusien kulutustottumusten vaikutukset suomalaisiin maalaisyhteisöihin 1800-luvun loppupuolella ja 1900-luvun alussa. Historiallinen Aikakauskirja 2009, I: 4-17.

Mitchell, Ian 2014. Tradition and Innovation in English Retailing, 1700 to 1850: Narratives of consumption. Farnham: Routledge.

NaAkKa-Korhonen, Mervi 1988. Halpa hinta, pitkä mitta: Vienankarjalainen laukkukauppa. Helsinki: Suomalaisen Kirjallisuuden Seura.

Nevalainen, Pekka 2016. Kulkukauppiaista kauppaneuvoksiin: Itäkarjalaisten liiketoimintaa Suomessa. Helsinki: Suomalaisen Kirjallisuuden Seura.

NYGÅRD, Henry 2004. Bara ett ringa obehag? Avfall och renhållning i de finländska städernas profylaktiska strategier 1830-1930. Åbo: Åbo Akademis Förlag.

Paloheimo, Maare \& Petri Karonen 2016. Raja taloudellisena mahdollisuutena: venäläiset kauppiaat Suomessa vuosina 1808-1820. Lähde: historiatieteellinen aikakauskirja 12: 174-199. 
PESONEn, Niilo 1980. Terveyden puolesta - sairautta vastaan: Terveyden- ja sairaanhoito Suomessa 1800- ja 1900luvulla. Porvoo: Werner Söderström Osakeyhtiö.

Rosander, Göran 1980. Gårdfarihandel i Norden. En översikt över en gammal handelsform. Stockholm: LTs förlag.

StARK, Laura 2011. The Limits of Patriarchy: How Female Networks of Pilfering and Gossip Sparked the First Debates on Rural Gender Rights in the 19th-Century Finnish-Language Press. (Studia Fennica Ethnologica 13) Helsinki: Suomalaisen Kirjallisuuden Seura.

STOR£, Nils 1989. Ostkarelische Wanderhändler als Kulturvermittler in Finnland. Jahrbuch für Volkskunde und Kulturgeschichte 32: 34-43.

STOR̊, Nils 1991. 'Rucksack Russians' in Finland: Peddling and culture contact. Ethnologia Scandinavica 21: 74-96.

StÅnlberg, Sabira 2012. Tatarerna - Finlands osynliga minoritet. Magma. Online: <magma.fi/tatarerna-finlandsosynliga-minoritet/>, accessed 1 July 2019.

Tervonen, Miika 2014. Historiankirjoitus ja myytti yhden kulttuurin Suomesta. In: P. Markkola, H. Snellman \& A.-C. Östman (eds), Kotiseutu ja kansakunta: Miten suomalaista historiaa on rakennettu (Historiallinen arkisto 142): 137-162. Helsinki: Suomalaisen Kirjallisuuden Seura.

Torvinen, Taimi 1989. Kadimah: Suomen juutalaisten historia. Helsinki: Otava.

Trentmann, Frank 2010. Multiple Spaces of Consumption: Some Historical Perspectives. In: M.K. Goodman, D. Goodman \& M. Redclift (eds), Consuming Spaces: Placing Consumption in Perspective: 41-56. Farnham: Ashgate.

Wassholm, Johanna 2017. Handel i marginalen. Den judiska småhandeln och lokalsamhället i Åbo i slutet av 1800talet. Historisk Tidskrift för Finland 102(4): 589-617.

Wassholm, Johanna 2018. Liikkuva kauppa ja kulttuurien kohtaaminen. Tataarien kulku- ja markkinakauppa Suomessa vuosina 1870-1920. In: M. Lamberg, U. Piela \& H. Snellman (eds), Sattunnaisesti Suomessa (Kalevalaseuran vuosikirja 97): 215-232. Helsinki: Suomalaisen Kirjallisuuden Seura.

Wassholm, Johanna \& Anna Sundelin 2018a. Emotions, trading practices and communication in transnational itinerant trade: encounters between 'Rucksack Russians' and their customers in the late nineteenth- and early twentieth-century Finland. Scandinavian Economic History Review 66(2): 132-152.

Wassholm, Johanna \& Anna Sundelin 2018b. Småskalig handel på glidande skalor. Historisk Tidskrift för Finland 103(2): 191-204.

WASSholm, Johanna \& Anna Sundelin 2018c. "Det hänger på ett hår”. Praktiker, moral och varuflöden i handeln med människohår i Finland 1870-1900. Historisk Tidskrift för Finland 103(2): 231-261.

WicKSTRÖM, Mats \& Charlotta WolfF 2016. Historiska perspektiv på mångkulturalitet, migration och minoriteter i Finlands historia. In: M. Wickström \& C. WolfF (eds), Mångkulturalitet, migration och minoriteter $i$ Finland under tre sekel (Skrifter utgivna av Svenska litteratursällskapet i Finland 803): 7-26. Helsingfors: Svenska litteratursällskapet i Finland. 